\title{
Third Global Forum of the Alliance of Civilizations
}

On 27 May 2010, a roundtable on "Addressing Islamophobia: Building on Unused Opportunities for Mutual Respect and Inclusion" took place on the sidelines of the Alliance of Civilizations' Third Global Forum. Held in Rio de Janeiro, Brazil, at the initiative of the Organization of the Islamic Conference (OIC), it was cosponsored by the Alliance of Civilizations (AoC), the Council of Europe, and the British Council.

After the initial remarks made by Ekmeleddin Ihsanoglu (secretary general, OIC) and Jorge Sampaio (UN High Representative for the AoC), the roundtable was addressed by a host of speakers and representatives of internationally reputed institutions, among them Marc de Brinchambaut (secretary general of the Organization for Security and Co-operation in Europe), Irina Bokova (director general, UNESCO), Mevlüt Çavusoglu (president, Parliamentary Assembly of the Council of Europe), André Azoulay (president, the Anna Lindh Euro-Mediterranean Foundation), and Mike Hardy (program leader, Intercultural Leader, the British Council). The session was moderated by Iqbal Riza (special advisor to the UN secretary-general for the Alliance of Civilizations). 
Ihsanoglu stated that the growing trend of Islamophobia, along with negative stereotyping, racial discrimination, and xenophobic treatment, was endangering global peace and security. Emphasizing that right-wing extremist elements in the West were gaining representation in the legislative bodies, particularly in Europe, and acting against Muslims and Islam in a concerted way, he cited Switzerland's constitutional amendment ban on building minarets in mosques. Such a mindset needs to change, he remarked, to bring about conditions for all civilizations and religions to live in peace and harmony. In this context, he reiterated his call for a historic reconciliation between Islam and Christianity and he referred to the initiative of the Custodian of the Two Holy Mosques, His Majesty King Abdullah Ibn Abdul Aziz Al Saud, to bring people together through developing a culture of peace and tolerance.

Participants underscored the fact that Islamophobia is a global, as opposed to a Muslim-only, concern. The roundtable reflected a common perception among participants on the present growing trend and negative effect of this phenomenon on global peace and security. This certainly indicates that an opportunity of a new beginning to deal with it on the basis of common understanding is knocking at the door and that all concerned need to build on this new-found common ground.

During the roundtable, it was decided that the panelists' contributions would be compiled and recorded as an outcome document of the session. This will serve as a reference for future endeavors to deal with this ever complex but crucially important issue.

During the opening session of the Third Global Forum of the Alliance of Civilizations, which occurred the following day, Ihsanoglu used his status as a high-level commentator of the Summit Plenary on Cultural Diversity as the Path to Peace to highlighted one particular fact: diversity, as a prevalent core value, is becoming a dominant factor in all aspects of modern life. He stressed that for this diversity to be fruitful, people had to be open as regards learning about each other's wisdom or culture, being self-critical, and making a distinction between theory and practice. In addition, they need to be able to challenge any tendency toward extremism and intolerance. For this goal to be realized, leaders and elites have to work with the grassroots, ordinary people from all walks of life, including the media and educators.

In the afternoon he addressed the "Ministerial Meeting of the UNAOC Group of Friends on Reinforcing Our Commitment with the Alliance," where he reiterated the OIC's readiness to cooperate fully with the $\mathrm{AoC}$ in building bridges among civilizations and cultures, underlining the example of the Custodian of the Two Holy Mosques, His Majesty King Abdullah Ibn Abdul 
Aziz Al Saud's initiative on international interfaith dialogue, as part of the commitment of the OIC and its member states for constructive engagement with diverse religions and civilizations.

The theme of calling for a historic reconciliation between Islam and Christianity, which could lead to setting aside old prejudices and moving the world toward reconciliation, harmony and prosperity, was prevalent throughout the event. Considering that the existing distrust between Islam and the West matters a fret deal to the rest of the world, this was only to be expected.

On 29 May 2010, Ihsanoglu attended the closing ceremony of the Third Forum of the Alliance of Civilisations, which rounded off its work. In a related development, the $\mathrm{OIC}$ signed an action plan with the $\mathrm{AoC}$ on the margin of the forum's third and final day-time sessions. OIC Secretary General Ihsanoglu signed for the OIC, and UN High Representative Jorge Sampaio signed on behalf of the AoC. The agreement seeks to devise joint plans and programs that will be implemented by the two sides during 201012. It follows an earlier memorandum of understanding, signed in Istanbul on the sidelines of the Second AoC Global Forum in 2009, lays the foundation of relations between the two organizations, and opens areas of greater cooperation between them as regards joint projects in opposing Islamophobia, improving engagement and dialogue activities to address the "MuslimWest divide," and each organization becoming more involved in the other's activities.

Abdula Manafi Mutualo Secretary, Islamophobia Observatory and Culture and Social Affairs Officer OIC General Secretariat, Jeddah, Saudi Arabia 